\section{Infant mortality and army families: a case-control study}

\section{K J Kimmance, W E Waters}

Salisbury Health Authority

KJ Kimmance, consultant in public health medicine

Department of Community Medicine, University of

Southampton,

Southampton

W E Waters, professorial fellow

Dr K Kimmance,

Department of Public

Health and Epidemiology,

Odstock Hospital, Salisbury

SP2 8BJ.

$B M 7$ 1992;305:1197 or inadequate description."
Correspondence to:

In the years 1976-90 infant mortality in the Salisbury health district was persistently higher than in England and Wales. This difference was mostly accounted for by post-neonatal deaths: post-neonatal death rate in Salisbury 5.6/1000 live births (95\% confidence interval 4.59 to 6.55 ); that in England and Wales 4.2/1000 live births $(4 \cdot 15$ to $4 \cdot 23)$. The district includes part of Salisbury Plain and several army establishments, and local health workers have long believed that the families of serving soldiers experience a higher infant mortality than the civilian population. At the 1981 census $10 \%$ of subjects resident in the health district were given the social class classification "armed forces

Previous studies examining perinatal and infant mortality in relation to military families have shown conflicting results. ${ }^{1-4} \mathrm{We}$ report a matched case-control study carried out to test the hypothesis that there is a greater risk of infant death in army families than in the general population.

\section{Methods and results}

The study period was from October 1983 to September 1991. Cases were defined as deaths under 1 year of age in children born in a hospital in the district who were resident until their death. Controls were matched for sex and age (that is, born as near to the date of birth of the case as possible and not more than five days either side); were born in a hospital in the district; and were still resident in the district at the date of death of the case. Twins were excluded. Two controls were chosen for each case. Statistical analysis of the matched sets of each case and associated controls was by the Mantel-Haenszel method. ${ }^{5}$ Data on cases and controls were obtained from hospital birth records. Families were defined as army or not army according to the father's occupation stated in the hospital records.

There were 91 cases, with a male to female ratio of $1 \cdot 5: 1$, and 182 matched controls. As shown in the table, there was over three times the proportion of

Proportions of army and not army families among infant deaths and controls. Matched cases and controls $(n=273)$

\begin{tabular}{|c|c|c|c|c|c|c|}
\hline & \multicolumn{2}{|c|}{ Infant deaths (cases) } & \multicolumn{2}{|c|}{ Controls } & \multirow{2}{*}{$\begin{array}{c}\text { Odds ratio } \\
(95 \% \text { confidence interval })\end{array}$} & \multirow[b]{2}{*}{$\mathrm{p}$ Value } \\
\hline & Army & Not army & Army & Not army & & \\
\hline All children & $14(18 \%)$ & 77 & $10(5 \%)$ & 172 & $2.8(1.29$ to 6.09$)$ & $p=0.009$ \\
\hline Neonatal (0-28 days) & $6(19 \%)$ & 32 & $2(3 \%)$ & 74 & $6 \quad(1.47$ to 24.45$)$ & $\mathrm{p}=0.012$ \\
\hline Post-neonatal (age $>28$ days) & $8(15 \%)$ & 45 & $8(8 \%)$ & 98 & $2(0.77$ to 5.23$)$ & $\mathrm{p}>0.05$ \\
\hline
\end{tabular}

army families among the infant deaths as among the controls. The difference was statistically significant $(p \leqslant 0.05)$ for all deaths and for neonatal deaths (birth to 28 days) but not for post-neonatal deaths. As expected, mothers of children who died were on average younger than mothers of controls (mean age 26.0 years compared with $27 \cdot 7$ years). However, analysis by age group of mother showed that the differences between army and not army persisted in all age groups, and therefore the younger average age of army mothers did not explain the positive association between infant death and army families. Also as expected, the average birth weight of the children who died was less than that of the controls. However, the birth weight of children of army families was no different from that of children in the general population.

\section{Comment}

This study confirmed the locally held view that there is a higher proportion of infant deaths in army families resident in the district than in the general population. This association is independent of the age of the mothers. The strong association of neonatal deaths with army families was not due to the sudden infant death syndrome because no case of the sudden infant death syndrome occurred in the district in neonates during the study.

What factors might be operating in army families? The selection of only resident children for the study excluded family migration after birth as a factor, but relatively frequent family moves might be important. If maternal smoking was a factor a difference in birth weight between army and not army families would have been expected; no such difference was found, although the numbers studied were small. Social class may be an important factor. Many serving personnel would be in social classes IV and V in civilian life, but their socioeconomic circumstances in the armed forces are probably different.

Further studies are needed into the reasons for high infant mortality in army families. In the mean time this section of the population should be accorded the attention due to a priority group in attempts to reduce infant mortality.

We thank Mrs Julia Lawler for help with the collection of data and for secretarial assistance.

1 Atalla MA, Page I, Oak M. Review of perinatal mortality in BAOR 1970-84. fR Army Med Corps 1986;132:173-6.

2 Rao M, Hoinville E. Review of post perinatal mortality in a health district with a garrison town. $B M F$ 1988;297:662.

3 Fedrick J. Sudden unexpected death in infants in the Oxford record linkage area. British fournal of Preventive and Social Medicine 1974;28:93-7.

4 Powell J, Machin D, Kershaw CR. Unexpected sudden infant deaths in Gosport--some comparisons between service and civilian families. $f R$ Nav Med Serv 1983;69:141-50.

5 Fleiss JL. Statistical methods for rates and proportions. New York: John Wiley and Sons, 1981. 